\title{
HUBUNGAN PENGGUNAAN KONTRASEPSI DENGAN KEJADIAN KEHAMILAN EKTOPIK TERGANGGU DI BLU RSUP PROF. DR. R. D. KANDOU MANADO PERIODE 2009 - 2013
}

\author{
${ }^{1}$ Deanette M. R. Aling \\ ${ }^{2}$ Juneke J. Kaeng \\ ${ }^{2}$ John Wantania
}

\author{
${ }^{1}$ Kandidat Skripsi Fakultas Kedokteran Universitas Sam Ratulangi Manado \\ ${ }^{2}$ Bagian Obstetri dan Ginekologi Fakultas Kedokteran Universitas Sam Ratulangi Manado \\ Email: aling.michelle@gmail.com
}

\begin{abstract}
Ectopic pregnancy accounts for 1 in 200 (5-6\%) maternal mortality in developed countries. ${ }^{2}$ According to the WHO, with over 60000 annual cases in Indonesia- that is 3\% of its population, the number of ectopic pregnancies in Indonesia is estimated to be on the brink to cases in developed countries. ${ }^{6}$ A risk factor for ectopic pregnancy that has surged over the years is the use of contraceptive methods. According to the research at the Department of Epidemiology and Social Medicine University of Brussels in the 90s and two consecutive research the at the Department of Obstetrics and Gynecology BLU RSUP Prof. dr. R. D. Kandou Manado in 2001 and 2011, the use of contraceptive methods have proven to have significant correlation with the incidence of ectopic pregnancy ( $>0.05) .{ }^{5,10}$ The issues above are what underlie the aim of this research - that is to investigate the possibility for ectopic pregnancies to occur in patients diagnosed with ectopic pregnancy with prior use of contraceptive methods at the Department of Obstetrics and Gynecology BLU RSUP Prof. dr. R. D. Kandou Manado from October 2009 - October 2013. The method applied for this research is by performing a 5 year retrospective study - analyzing the number of patients with ectopic pregnancy as well as those with prior use of contraceptive methods. The result from a ChiSquare analysis is $p=0.457$, where if $p<0.05$, means there is a significant correlation. Thus with such result, it is proven that there is no significant correlation between the use of contraceptive methods with the incidence of ectopic pregnancy.
\end{abstract}

Keywords: ectopic pregnancy, contraceptive methods.

Abstrak: Kehamilan Ektopik Terganggu (KET) merupakan penyebab 1 dari 200 (5-6\%) mortalitas maternal di negara maju. ${ }^{2}$ Dengan 60.000 kasus setiap tahun atau 3\% dari populasi masyarakat, angka kejadian KET di Indonesia diperkirakan tidak jauh berbeda dengan negara maju, menurut WHO. ${ }^{6}$ Adapun salah satu faktor risiko KET yang dinilai semakin meningkat dewasa ini adalah pemakaian alat-alat/ metode kontrasepsi. Ditinjau dari penelitian di Department of Epidemiology and Social Medicine University of Brussels pada tahun 90an dan penelitian di BLU RSUP Prof. dr. R. D. Kandou Manado pada tahun 2001 dan 2011, pemakaian alat kontrasepsi dengan kejadian KET memiliki hubungan yang signifikan, dengan $\mathrm{p}>0.05$. Masalah tersebut yang menjadi dasar tujuan penelitian ini, yaitu untuk menindaklanjuti kemungkinan terjadinya KET pada pasien-pasien KET dengan riwayat pemakaian kontrasepsi, dengan memberikan gambaran mengenai data-data kasus KET dengan riwayat penggunaan kontrasepsi yang diperiksa di bagian Obstetri dan Ginekologi BLU RSUP Prof. dr. R. D. Kandou Manado periode Oktober 2009 - Oktober 2013.Metode yang digunakan pada penelitian ini adalah dengan melakukan studi retrospektif, yaitu dengan melakukan pendataan jumlah pasien KET, serta riwayat penggunaan kontrasepsi oleh pasien-pasien KET tersebut dalam kurun waktu 5 tahun. Hasil yang ditemukan memperlihatkan hasil uji Chi-Square adalah $\mathrm{p}=0.457$, dimana jika nilai $\mathrm{p}<$ 0.05, maka dikatakan terdapat hubungan yang signifikan. Oleh karena nilai p pada uji Chi-Square di tabel 4.4.A >0.05, maka dapat dikatakan bahwa tidak terdapat hubungan yang signifikan antara riwayat penggunaan kontrasepsi dengan kejadian KET.

Kata kunci: KET (Kehamilan Ektopik Terganggu), kontrasepsi. 
Kehamilan Ektopik Terganggu (KET) merupakan salah satu masalah di bidang ginekologi yang berkontribusi pada mortalitas maternal. ${ }^{3,4}$ Menurut American College of Obstericians and Gynecologists (2008), 2\% dari seluruh kehamilan di trimester pertama di Amerika Serikat adalah kehamilan ektopik. Jumlah ini berkontribusi sekitar 6\% pada semua kematian terkait kehamilan. ${ }^{3}$

Riset World Health Organization (WHO) 2007 menunjukkan bahwa, KET merupakan penyebab satu dari 200 (5-6\%) mortalitas maternal di negara maju. ${ }^{2}$ Dengan 60.000 kasus setiap tahun atau 3\% dari populasi masyarakat, angka kejadian KET di Indonesia diperkirakan tidak jauh berbeda dengan negara maju, menurut WHO. ${ }^{6}$

Salah satu dari beberapa faktor risiko KET yang prominen adalah kegagalan penggunaan kontrasepsi. ${ }^{2}$ Kontrasepsi merupakan metode handal dalam mencegah kehamilan, namun masih terdapat celah untuk terjadinya kegagalan dalam pengunaannya. Pada sebagian kegagalan kontrasepsi, jumlah relatif kehamilan ektopik meningkat. Contohnya antara lain, beberapa bentuk sterilisasi tuba, Alat Kontrasepsi Dalam Rahim (AKDR), kontrasepsi darurat (EC) estrogen dosis tinggi dan mini pills yang hanya mengandung progestin. ${ }^{2}$

Studi meta analisis literatur mengenai hubungan penggunaan dan risiko kehamilan ektopik dari tahun 1977 sampai 1994 oleh Department of Epidemiology and Social Medicine University of Brussels, Belgium menemukan Odds Ratio (OR) gabungan 10,63 pada wanita pengguna AKDR dibandingkan dengan dengan wanita hamil sebagai variable kontrol. Hal ini menunjukkan signifikansi hubungan antara penggunaan AKDR dengan KET, dengan hasil OR lebih besar dari nilai $\mathrm{p}=0,05$. $^{7}$

Adapun hasil penelitian dari beberapa rumah sakit di Indonesia yang menunjukkan hubungan penggunaan kontrasepsi dengan KET. Hasil penelitian Suparman di BLU RSUP Prof. dr. R. D. Kandou Manado tahun 2001, menunjukkan bahwa angka kejadian KET meningkat pada penggunaan alat kontrasepsi yaitu berjumlah 48 jiwa (71,63\%) dibandingkan dengan yang tidak menggunakan alat kontrasepsi, yaitu berjumlah 19 jiwa (28,36\%). Hasil ini menjadi salah satu acuan dari penelitian deskriptif selanjutnya tentang distribusi penderita KET yang disebabkan oleh pemakaian kontrasepsi di rumah sakit yang sama pada periode 1 Januari 2010- 31 Desember 2011, dimana ditemukan total sebanyak 15 kasus KET yang disebabkan oleh pemakaian kontrasepsi dari 41 kasus yang terdiagnosis KET.

\section{METODE PENELITIAN}

Penelitian ini merupakan penelitian analitik dengan pendekatan studi retrospektif, yaitu dengan melakukan pendataan jumlah pasien KET, serta riwayat penggunaan kontrasepsi oleh pasien-pasien KET tersebut.Penelitian dilakukan pada bulan Oktober-November 2014. Sedangkan lokasi penelian, bertempat di Bagian Obstetri dan Ginekologi BLU RSUP Prof. dr. R. D. Kandou Manado. Populasi adalah semua pasien KET di bagian Obstetri dan Ginekologi BLU RSUP Prof. dr. R. D. Kandou Manado dalam 5 tahun terakhir, yaitu periode 2009 - 2013. Variabel bebas dalam penelitian ini adalah penggunaan alat kontrasepsi, sedangkan variabel terikat adalah kejadian Kehamilan Ektopik Terganggu (KET).

Data yang digunakan dalam penelitian bersifat sekunder, yang diperoleh dari rekam medis wanita dengan KET. Selanjutnya, data dianalisa dengan sistim tabulasi bentuk distribusi frekuensi dan diuji dalam bentuk analisis univariat untuk mendeskripsikan data yang didapat, menggunakan SPSS versi 16.0 .

\section{HASIL \& PEMBAHASAN}

Setelah melalui tahap pendataan, jumlah pasien KET periode 2009 - 2013 di Bagian Obstetri BLU RSUP Prof. dr. R. D. Kandou Manado berjumlah 271 orang.

Adapun karakteristik sampel penelitian hanya ditinjau berdasarkan umur pasien, karena merupakan hal yang relevan dalam penelitian ini. Oleh karena itu, kategori umur pasien dibagi menjadi $<20$ tahun, 20- 
Aling, Kaeng, Wantania; Hubungan Penggunaan Kontrasepsi...

24 tahun, 25-29 tahun, 30-34 tahun, 35-39 tahun dan 40 tahun. Gambaran distribusi pasien KET sesuai umur dapat dilihat pada Tabel berikut:

Tabel 1.Karakteristik berdasarkan umur

\begin{tabular}{ccc}
\hline Umur & $\mathbf{n}$ & Persentase (\%) \\
\hline$<20$ & 8 & 3 \\
$20-24$ & 44 & 16.2 \\
$25-29$ & 56 & 20.7 \\
$30-34$ & 84 & 31 \\
$35-39$ & 57 & 21 \\
$40>$ & 22 & 8.1 \\
Total & 271 & 100 \\
\hline
\end{tabular}

Berdasarkan Tabel 1, pasien KET distribusi umur pasien KET terbanyak adalah pada kelompok usia 30-34 tahun, yaitu berjumlah 86 (32\%) dari 271 pasien. Penelitian tentang insiden kehamilan ektopik di Ebony State University Teaching Hospital, Abakaliki, Nigeria periode Juni 2002 sampai Mei 2012 menunjukkan bahwa, jumlah pasien KET terbanyak terdapat pada kelompok usia 25-29 tahun, yaitu 88\% dari 205 pasien. ${ }^{9}$ Oleh karena itu, berdasarkan perbandingan dari penelitian diatas, dapat disimpulkan bahwa usia rentan terjadinya KET pada wanita adalah pada usia 25-35 tahun. ${ }^{6}$ Hal ini tidak mengejutkan dikarenakan selain usia 20-30 tahun merupakan usia reproduksi, wanita dalam kelompok usia ini memiliki risiko aktifitas secara seksual yang tinggi. ${ }^{9}$

Selanjutnya, dilakukan analisis univariat pada riwayat penggunaan kontrasepsi untuk mengetahui jika penggunaan kontrasepsi terbukti memiliki hubungan yang signifikan dengan kejadian KET, jenis kontrasepsi mana yang cenderung memiliki risiko terbesar menyebabkan KET. Selain itu, distribusi lokasi KET pada pasien juga dianalisa pada penelitian ini. Hasil analisis univariat kedua kategori ini, dapat dilihat pada kedua tabel berikut:
Tabel 2. Distribusi frekuensi riwayat penggunaan kontrasepsi pada pasien KET

\begin{tabular}{|c|c|}
\hline $\begin{array}{l}\text { Riwayat } \\
\text { Penggunaan } \\
\text { Kontrasepsi }\end{array}$ & $\begin{array}{l}\text { Persentase } \\
\text { (\%) }\end{array}$ \\
\hline $\begin{array}{l}\text { Tidak menggunakan } \\
\text { Kontrasepsi }\end{array}$ & 51.7 \\
\hline $\begin{array}{l}\text { Menggunakan } \\
\text { Kontrasepsi }\end{array}$ & 48.3 \\
\hline KB Suntik & 31.4 \\
\hline Pil KB & 11.4 \\
\hline AKDR & 3.7 \\
\hline Susuk & 1.5 \\
\hline Kondom & 0.4 \\
\hline Total & 100 \\
\hline
\end{tabular}

Tabel 2 menunjukkan bahwa, jumlah pasien KET yang memiliki riwayat kontrasepsi dengan yang tidak memiliki riwayat kontrasepsi, hampir terbagi rata, dengan 140 pasien (52\%) yang memiliki riwayat kontrasepsi dan 131 pasien (48\%) yang tidak. Penemuan ini membuktikan bahwa baik yang menggunakan kontrasepsi atau tidak, memiliki peluang yang hampir sama untuk terkena KET. Adapun hal ini, kontra dengan penelitian Suparman di BLU RSUP Prof. dr. R. D. Kandou Manado tahun 2001, dimana angka kejadian KET meningkat pada penggunaan alat kontrasepsi dibandingkan dengan yang tidak menggunakan alat kontrasepsi, dengan perbandingan $2: 1{ }^{6}$

Adapun pasien yang memiliki riwayat kontrasepsi, dibagi berdasarkan jenis kontrasepsi yang dipilih yaitu, KB Suntik berjumlah 85 pasien (31\%), Pil KB sebanyak 31 pasien (11\%), AKDR sebanyak 10 orang (4\%), Susuk sebanyak 4 orang (1\%).Terlihat jelas bahwa, jenis kontrasepsi yang paling banyak diminati adalah KB Suntik Depo Progestin. Hasil ini sesuai dengan data BKKBN Nasional tentang hasil pelayanan peserta KB baru tahun 2012, dimana KB suntik merupakan metode yang paling banyak dipilih. ${ }^{10}$ Banyak pula wanita memilih KB Suntik dikarenakan metode ini lebih praktis, dan dapat mengembalikan kesuburan dalam jangka waktu yang cukup singkat, yaitu 6-10 bulan. ${ }^{8}$ 
Tabel 3. Distribusi frekuensi lokasi KET pada pasien KET

\begin{tabular}{lcc}
\hline Lokasi KET & n & $\begin{array}{c}\text { Persentase } \\
(\%)\end{array}$ \\
\hline Tuba Sinistra & 121 & 44.6 \\
Tuba Dextra & 148 & 54.6 \\
Ovarium Sinistra & 1 & 0.4 \\
Ovarium Dextra & 1 & 0.4 \\
Serviks & 0 & 0 \\
Abdomen & 0 & 0 \\
Jaringan Parut & & \\
Caesar & 0 & 0 \\
Total & 271 & 100 \\
\hline
\end{tabular}

Tabel 3 menunjukkan bahwa, lokasi KET paling sering adalah pada tuba, khususnya di tuba dextra, yaitu sebanyak 148 pasien (55\%), diikuti dengan tuba sinistra dengan 121 pasien (45\%). Jumlah pasien dengan KET pada ovarium sinistra dan dextra terbagi rata, yaitu 1 pasien (0.4\%) pada tiap lokasi, sedangkan pada lokasi KET yang lain, tidak ditemukan pasien KET pada penelitian ini. Temuan ini sesuai dengan hasil dari beberapa studi sebelumya, dimana lokasi paling sering terjadinya kehamilan ektopik adalah pada tuba. $^{9,5,6}$ Adapun hasil dari penelitian ini turut mendukung beberapa studi tersebut dikarenakan oleh angka kejadian yang mencakup hampir seluruh sampel penelitian (99.2\%), tuba falopiterbukti adalah lokasi paling sering terjadinya KET, dengan 55\% KET terjadi pada tuba dextra dan $45 \%$ pada tuba sinistra. Hal ini disebabkan karena tuba falopi sangat banyak mengandung serat elastik, pembuluh darah dan limfatik.Selain itu, tuba falopi juga tidak memiliki lapisan sub mukosa. Pada akhirnya, ovum yang telah dibuahi, segera menembus epitel, dan zigot akhirnya terimplantasi di dekat atau di dalam otot tuba, dan bertahan karena suplai nutrisi yang adekuat dari pembuluh darah sekitar. $^{3}$

Tabel 4 memperlihatkan hasil uji ChiSquare adalah $\mathrm{p}=0.457$, dimana jika nilai $\mathrm{p}$ $<0.05$, maka dikatakan terdapat hubungan yang signifikan. Oleh karena nilai p pada uji Chi-Square di tabel 4.4.A>0.05, maka dapat
Tabel 4. Hasil uji Chi-Square hubungan riwayat penggunaan kontrasepsi dengan kejadian KET

\begin{tabular}{lccc}
\hline $\begin{array}{l}\text { Penggunaan } \\
\text { Kontrasepsi }\end{array}$ & $\begin{array}{c}\text { Kejadian KET } \\
\mathbf{2 0 0 9}-\mathbf{2 0 1 3} \\
\text { Persentase } \\
\text { (\%) }\end{array}$ & $\begin{array}{c}\text { Nilai p } \\
<0,05\end{array}$ \\
\hline $\begin{array}{l}\text { Tidak menggunakan } \\
\text { Kontrasepsi }\end{array}$ & 140 & 52 & \\
$\begin{array}{l}\text { Menggunakan } \\
\text { Kontrasepsi }\end{array}$ & 131 & 48 & 0,457 \\
Total & & & \\
\hline
\end{tabular}

dikatakan bahwa tidak terdapat hubungan yang signifikan antara riwayat penggunaan kontrasepsi dengan kejadian KET.

Hasil ini sama halnya dengan penelitian yang dilakukan oleh K.T. Barnhart, dimana dijelaskan bahwa tidak ada hubungan yang jelas antara penggunaan kontrasepsi dengan terjadinya kehamilan ektopik, namun diperkirakan senggama selagi menggunakan AKDR, dapat meningkatkan faktor risiko sebesar 25-50\%. ${ }^{1}$ Meski tidak terdapat hubungan yang signifikan secara statistik antara riwayat penggunaan kontrasepsi dan kejadian KET pada penelitian ini, namun terbukti bahwa hampir 50\% pasien KET memiliki riwayat penggunaan kontrasepsi. Oleh karena itu, dapat disimpulkan bahwa, penggunaan kontrasepsi dapat menjadi faktor risiko terjadinya KET. ${ }^{3}$

\section{SIMPULAN \& SARAN}

Berdasarkan hasil penelitian yang dilakukan di Bagian Obstetri dan Ginekologi BLU RSUP Prof. dr. R. D. Kandou Manado, dapat disimpulkan bahwa tidak terdapat hubungan antara riwayat penggunaan kontrasepsi dengan kejadian KET dilihat dari nilai $\mathrm{p}=0.457(\mathrm{p}>0.05)$. Namun, perluada penelitian-penelitian baru untuk menindak lanjuti kasus kehamilan ektopik di sejumlah rumah sakit di kota Manado, bahkan dalam skala nasional, agar faktor-faktor KET lainnya dapat teridentifikasi, sehingga pencegahan dan penanggulangan dini KET dapat terlaksana secara cepat dan seksama. 


\section{DAFTAR PUSTAKA}

1. Barnhart KT. Ectopic Pregnancy. N ENGL J MED. 2009;361:379-87.

2. Berek J. Berek \& Novak's Gynecology. $15^{\text {th }}$ Ed. Philadelphia: Lippincot Williams \& Wilkins; 2012.h.214.

3. Cunningham, Leveno, Bloom, Hauth, Rouse, Spong. Williams Obstetrics. $23^{\text {rd }}$ Ed. Dallas: McGraw-Hill Companies, Inc; 2010.h. 251-67.

4. J.L.V. Shaw, S.K. Dey, H.O.D. Critchley, A.W. Horne. Current knowledge of the aetiology of human tubal ectopic pregnancy. Human Reproduction Update. 2010;16:432444

5. Logor S, Wagey F, Loho M. Tinjauan Kasus Kehamilan Ektopik di BLU RSUP Prof. dr. R. D. Kandou Manado periode Januari 2010 - 31 Desember. Jurnal eBM. 2013;1(1):4044.
6. Suryawan A. Gunanegara H, Sastrawinata U. Profil Penderita Kehamilan Ektopik Terganggu periode 1 Januari 2003 - 31 Desember 2004 di RS Immanuel Bandung. JKM. 2007;6(2):1-3.

7. Woolrych H, Wooley. Progestogen-only emergency contraception and ectopic pregnancy. BMJ. Journal of Family Planning and Reproductive Health Care. 2003;29(1):5-6.

8. Saifuddin AB. Buku Panduan Praktis Pelayanan Kontrasepsi. Jakarta: Yayasan Bina Purtaka Sarwono Prawirohardjo; 2003.

9. Lawani O, Okechukwu A, Ezeonu P. Ectopic pregnancy: a life-threatening gynecological emergency. International Journal of Women's Health 2013;5:515521.

10. Badan Pusat Statistik (BPS). Laporan Pendahuluan Survei Demografi dan Kesehatan Indonesia tahun 2012. Jakarta: Badan Pusat Statistik; 2012. h.9. 